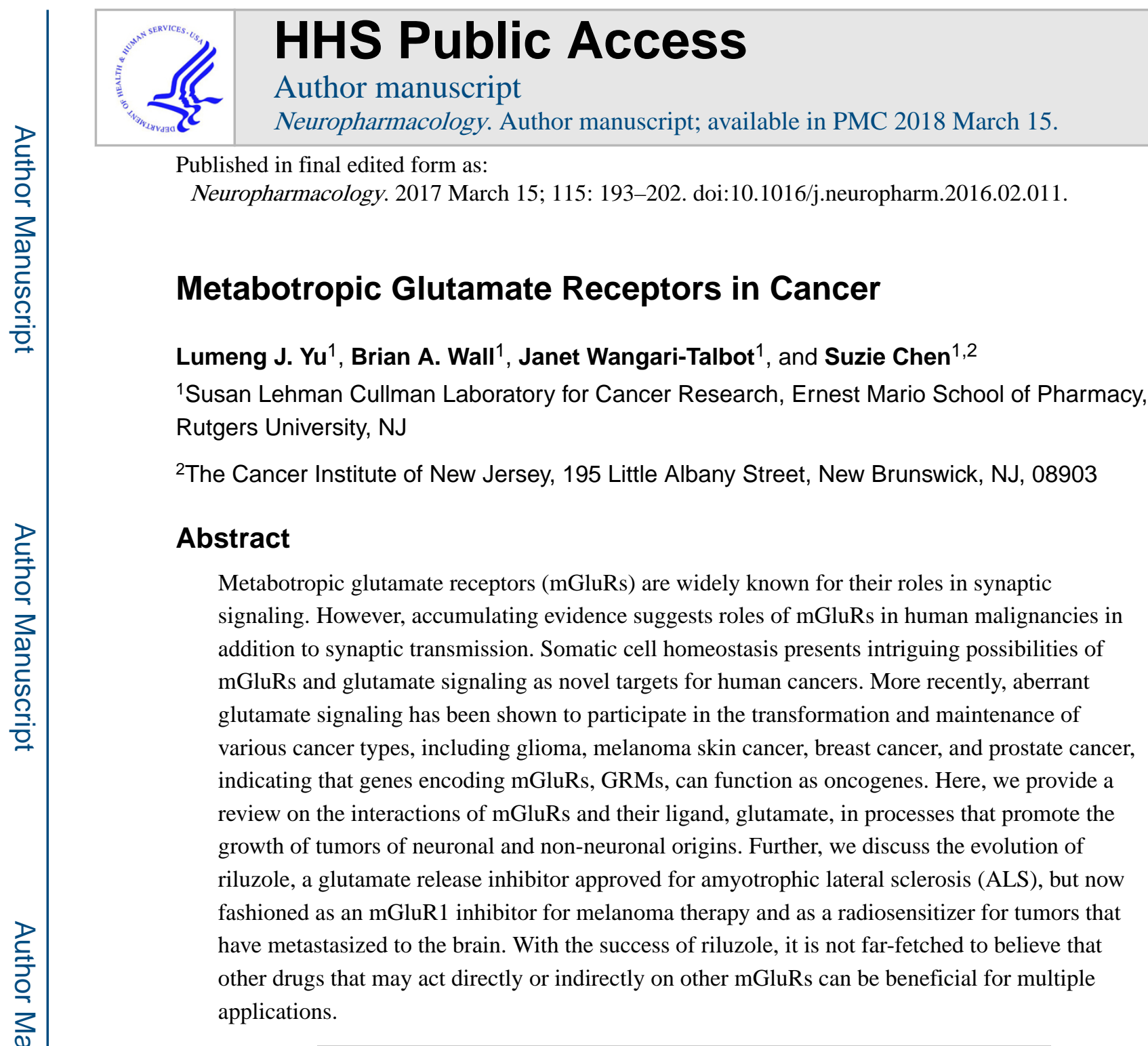

\title{
Glutamine and Glutamate
}

Glutamate plays an innate role in the human central nervous system as an excitatory neurotransmitter in processes such as learning and memory formation (Alix and Domingues, 2011; Fairman and Amara, 1999). Its role in cellular homeostasis is related to both its function in nitrogen metabolism and disposal, as well as its use as a metabolic fuel for energy-producing pathways (Dimski et al., 2008; Kelly and Stanley, 2001; Spanaki and Plaitakis, 2012). In addition, it has long been established that excess glutamate causes neuronal excitotoxicity; more recent findings have also implicated functional glutamate signaling in transformation and progression of various cancers (Prickett and Samuels, 2012; Ribeiro et al., 2010; Willard and Koochekpour, 2013). Glutamine is preferred as fuel in tumor cells over glucose because of its properties enabling it to act to both fulfill energy requirements as well as serve as an intermediate for macromolecule synthesis (Deberardinis

\footnotetext{
Publisher's Disclaimer: This is a PDF file of an unedited manuscript that has been accepted for publication. As a service to our customers we are providing this early version of the manuscript. The manuscript will undergo copyediting, typesetting, and review of the resulting proof before it is published in its final citable form. Please note that during the production process errors may be discovered which could affect the content, and all legal disclaimers that apply to the journal pertain.
} 
et al., 2008; Moreadith and Lehninger, 1984; Wall et al., 2013). The dual role of glutamine derives from its structure. Reactions such as nucleotide synthesis may directly use its $\gamma$ nitrogen, whereas the a-nitrogen and its carbon skeleton can be used indirectly in reactions for energy production and biosynthesis (Gaglio et al., 2009). Cell growth requires these metabolic intermediates, and is propagated by the conversion of glutamine to glutamate by phosphate-dependent glutaminase (GLS) in the inner mitochondrial membrane (Figure 1) (Cairns et al., 2011; Marie and Shinjo, 2011). This enzyme is overexpressed in many tumor types, and is a primary driver of glutamine consumption in cancer cells, leading to large intracellular pools of glutamate and subsequent glutamate release, the implications of which will be discussed later in this chapter (Cairns et al., 2011; Marie and Shinjo, 2011; Wall et al., 2013).

The conversion of glutamine to glutamate and ammonia constitutes the first and rate-limiting step of glutaminolysis. The resulting glutamate is used as a primary source of energy for proliferating cells, but can then be further metabolized to a-ketoglutarate in the mitochondrial matrix. Subsequent breakdown generates NADPH for use as an electron donor, which is also used to maintain glutathione (GSH), a key antioxidant, in its reduced state, thus keeping oxidative stress in check in rapidly growing cells (DeBerardinis et al., 2007; Estrela et al., 2006; Wall et al., 2013). Recently, several groups identified reductively metabolized glutamine as the major carbon source during hypoxia and limited respiration. Reductive metabolism is known to be preferred within the hypoxic conditions of most tumor environments, the result of a tumor's outpacing the development of an effective blood supply, among other conditions, and is due to the stabilization of a transcription factor, hypoxia-induced factor la (HIF-1a). Notably, HIF-1a induction and reductive metabolism occur in tumor cells growing in normoxic conditions as well, pointing to a more general role in sustaining tumor growth (Fendt et al., 2013; Filipp et al., 2012; Gameiro et al., 2013; Gao et al., 2009; Karakas et al., 2015; Niklas and Heinzle, 2012; Sun and Denko, 2014; Wise et al., 2008; Wise et al., 2011; Zamboni, 2011).

\section{mGluRs in cancer}

Overexpression or aberrant expression of GPCRs has been detected in many cancer cell types, and contributes to tumor cell growth by paracrine or autocrine signaling, maintaining an activated state that leads to enhanced cellular proliferation via downstream effector proteins (Table 2) (Bhowmick et al., 2004; Burger et al., 1999; Cheng et al., 2008; Takayama et al., 1997). In particular, mGluRs have been shown empirically to be the predominant mediators of glutamatergic signaling in many cancers (Khan et al., 2011; Koochekpour, 2013; Martino et al., 2013; Speyer et al., 2014; Teh and Chen, 2012; Zhang et al., 2015). The mechanisms by which mGluRs modulate peripheral cell transformation and tumor growth are postulated to be either ectopic expression of wild type mGluRs, increased proliferative signals arising from receptor overexpression, mutations, or expression of polymorphic variants (Ali et al., 2014; Brocke et al., 2010; Mehta et al., 2013; Namkoong et al., 2007; Wall et al., 2014; Zhang et al., 2015). 


\section{mGluRs in primary brain tumors}

The first observations of mGluRs in human malignancies were in neuronal tumors including neuroblastomas, medulloblastomas, and gliomas (Iacovelli et al., 2006; Naarala et al., 1993;

Shin et al., 2008; Takano et al., 2001). In normal brain, astrocytes primarily express mGluR3, whereas glial cells express mGluR1 and mGluR5 (Balazs et al., 1997; Petralia et al., 1996; Wroblewska et al., 1998). In a comprehensive study of pediatric brain tumors, mGluR1, mGluR2, and mGluR6 display elevated expression levels in malignant medulloblastomas, ependymomas, and glioblastomas, compared to low-grade astrocytomas (Brocke et al., 2010). Additionally, these overexpression patterns were similar among different tumor cell types, despite distinct histological origins, possibly pointing to common glutamatergic signaling as a key player in these cancers and could be aimed as a therapeutic target in childhood brain tumors (Brocke et al., 2010). Both groups I and II mGluRs have been implicated in glioma. Inhibition of mGluR1 significantly decreases cell viability in U87 glioma cells, resulting in apoptosis via mitigated activation of the PI3K/Akt/mTOR pathway (Zhang et al., 2015). These results also translated to a U87 xenograft glioma model, indicating possible clinical relevance for the use of mGluR1 inhibitors in glioma treatment (Zhang et al., 2015). Another group showed that group II mGluRs, mGluR2/3, are expressed in a majority of human glioblastoma specimens. In vitro cultured cell studies showed suppression of cell growth in the presence of an mGluR2/3 antagonist; removal of the antagonist restored cell growth (D'Onofrio et al., 2003). Additionally in U87 glioma cells, use of mGluR2/3 antagonist abrogated cyclin D1/D2 expression and activated both MAPK and PI3K pathways (Arcella et al., 2005). Aronica and colleagues showed that mGluR3 and mGluR5 agonists modulate the expression of the glutamate transport proteins, GLAST, GLT-1 and EAAT. Selective group I agonists downregulated expression of GLAST and GLT-1 in astrocytes, while group II agonist positively induced the expression of the transporters. Similar observations were noted with the EAAT transporter when glioblastoma cells were treated with group I or II agonists. Selective antagonists of group I and II mGluRs prevented the induction of these receptors and further, inhibition of MAPK and PI3K signaling had a negative effect on the expression of the GLAST and GLT-1 induced by the agonists. Taken together, these results point to complex interactions between various modulators of mGluRs and also suggest the potential use of glutamate receptor agonists to manipulate glutamate levels in brain tumor environments by targeting glutamate transporter expression (Aronica et al., 2003). In malignant gliomas, mGluR3 can regulate chemoresistance to the alkalizing agent, temozolomide, and the level of mGluR3 from human glioblastoma multiforme samples is inversely related to survival following surgery and adjuvant chemotherapy (Ciceroni et al., 2013). On the contrary, activation of the group III mGluR, mGluR4, has been demonstrated to inhibit growth of medulloblastoma. Sixty samples of human medulloblastoma were examined, and approximately $77 \%$ expressed mGluR4, which was inversely correlated with tumor severity, spread, and recurrence (Iacovelli et al., 2006). In addition, in medulloblastoma cell lines, mGluR4 activated with a selective enhancer led to inhibition of adenylate cyclase and PI3K pathways, reduced DNA synthesis and cell proliferation (Iacovelli et al., 2006). Further in vivo studies identified that stimulated mGluR4 inhibits medulloblastoma cell xenografts progression in nude mice, and treatment with an mGluR4 enhancer in the first week of life is able to prevent the 
development of medulloblastoma in an irradiated, heterozygous Patched-1 mouse model (Iacovelli et al., 2006). These data suggest that disrupted glutamate signaling is involved in primary CNS tumors.

\section{mGluRs in non-neuronal cancers}

Among Group I mGluRs, mGluR1 has been shown to induce the neoplastic transformation of immortalized baby mouse kidney epithelial cells (iBMK) in vitro and promote tumor cell progression in vivo (Degenhardt and White, 2006; Martino et al., 2013). It was shown that full-length wild-type mGluR1 is oncogenic when exogenously introduced in epithelial cells that led to stimulated MAPK and AKT signaling pathways. In addition, mutations and single nucleotide polymorphisms (SNPs) of GRM1 have also been described in prostate cancer (Ali et al., 2014). These mutations may serve to modulate mGluR1 by altering gene splicing, ligand binding, and downstream signaling. Eight somatic variations of GRM1 have been identified in cancers, including lung adenocarcinoma where GRM1 mutations have been demonstrated to result in functional downstream signaling with variable modulation of cell proliferation pathways including MAPK/ERK (Esseltine and Ferguson, 2013). mGluR5 overexpression has been shown to induce melanoma development in transgenic mice as well (Choi et al., 2011). Increased expression of mGluR5 in the mouse melanocytes was correlated with enhanced levels of MAPK activation, suggesting that glutamatergic signaling plays a significant role not only in the initiation and progression, but also in the maintenance, of tumorigenesis. mGluR5 has also been implicated in oral squamous cell carcinoma as well as laryngeal cancers. Park and colleagues showed that differential levels of mGluR5 are expressed in human oral squamous cell carcinomas with increased mGluR5 immunoreactivity associated with improved overall survival (Park et al., 2007). Additionally, a mGluR5 agonist promoted tumor cell migration, invasion, and adhesion in human tongue cancer cells, which was reversed by an mGluR5 antagonist (Park et al., 2007). Subsequent studies showed that inhibition of mGluR5 with specific antagonist reduces metastasis in CXCR4/stromal-derived factor-1 (SDF-1)-dependent oral cancers (Kuribayashi et al., 2013). In laryngeal cancer, the mGluR5 antagonist, MPEP, inhibits cell proliferation, although its expression is much lower than that in the brain, which may account for the relatively weak response of laryngeal cancer cells to mGluR antagonists (Stepulak et al., 2011). In addition to mGluR5, mGluR4 NMDA and AMPA mediated glutamate signaling have also been observed in laryngeal cancers (Chang et al., 2005; Stepulak et al., 2011).

Group II mGluRs have also been implicated in a variety of cancer types, including melanoma. Notably, through exon capture sequencing of GPCRs in malignant melanoma, the Samuels group identified hot spots in GRM3 that are frequently mutated in human melanoma and selectively regulate phosphorylation of MEK, leading to anchorageindependent growth and migratory capabilities in cultured cells (Prickett et al., 2011). The mutations were found throughout the coding region and affected the extracellular domains as well as the seven-transmembrane domain, with two mini-hotspots located proximal to the transmembrane domain. Four somatic mutations (mGluR3 ${ }^{\mathrm{E} 767 \mathrm{~K}}$, mGluR3 ${ }^{\mathrm{S} 610 \mathrm{~L}}$, $\mathrm{mGluR}^{\mathrm{G} 561 \mathrm{E}}$, and $\mathrm{mGluR} 3^{\mathrm{E} 870 \mathrm{~K}}$ ) were found to selectively regulate phosphorylation of MEK1/2 kinase in vitro and induce micro metastasis in vivo. These studies suggest a subset

Neuropharmacology. Author manuscript; available in PMC 2018 March 15. 
of melanomas in which activating mutations in mGluR3 lead to hypersensitivity to agonist stimulation of the MEK-MAPK pathway without involvement of RAF/RAS genotypes.

Finally, Group III mGluRs have been implicated in colorectal, laryngeal squamous cell, breast cancers, and osteosarcoma, as well as malignant melanoma. Chang and colleagues have reported that mGluR 4 is overexpressed in more than $40 \%$ of colorectal adenocarcinomas, malignant melanomas, laryngeal squamous cell carcinomas, and breast carcinomas, and that overexpression of the receptor was correlated with increased mortality in colorectal carcinoma (Chang et al., 2005). The same group had previously demonstrated that human colon cancer cells resistant to 5-FU overexpress mGluR4, and that mGluR4 agonists enhanced 5-FU resistance while mGluR4 antagonists ablated 5-FU resistance (Yoo et al., 2004). Savage and colleagues also identified two susceptibility loci for osteosarcoma in the gene encoding mGluR4 (Savage et al., 2013). More recently, increased expression of mGluR4 and mGluR8 in a lung carcinoma cell line and human lung adenocarcinoma samples was reported. Further studies revealed that an mGluR8 agonist (S)-3,4-DCPG reduced cell growth and increased apoptosis, indicating that mGluR8 could be a potential target in future lung cancer therapies (Li et al., 2015).

In the next few sections, the role of mGluR1 in melanoma and breast cancer is discussed in detail. Extensive studies on the involvement of mGluR1 in melanoma and triple negative breasts have been performed and resulted in clinically tested treatments that target the receptor.

\section{mGluR1 in melanoma}

Our group has previously described an unknown mechanism of melanoma pathogenesis in which the aberrant expression of mGluR1 in melanocytes is sufficient to transform melanocytes in vitro and promote melanoma tumor development in vivo (Chen et al., 1996; Zhu et al., 1998). Chen and colleagues established a transgenic mouse line, TG-3, that harbors a 2-kb genomic fragment, clone $\mathrm{B}$, which had previously been shown to commit fibroblasts to undergo adipocyte differentiation in vitro (Chen et al., 1996; Zhu et al., 1998). Instead of the expected obese phenotype, one founder, TG-3, developed pigmented lesions on the ears, around the eyes, and in the perianal region, identified as melanoma by histological means. Molecular and biochemical analyses revealed that melanoma development in the TG-3 mouse model was a result of a classic case of insertional mutagenesis that led to ectopic expression of mGluR1 in melanocytes. Insertion of clone B resulted in concurrent deletion of approximately $70 \mathrm{~kb}$ of host sequence in intron 3 of the gene encoding mGluR1, GRM1 (Pollock et al., 2003; Wall et al., 2013). Further analysis of the pigmented lesions on TG-3 revealed that murine mGluR1 was expressed both on the protein and mRNA levels, but appeared to be low/absent in the normal skin of the animal (Pollock et al., 2003; Wall et al., 2013). A new transgenic mouse line, TG(Grm1)EPv, or "E", was created, using wild-type murine GRM1 cDNA under the control of a melanocytespecific promoter dopachrome tautomerase (Dct) (Pollock et al., 2003). This new mouse line displays a melanoma susceptibility profile similar to that of the original TG-3 founder. We concluded that ectopic expression of mGluR1 in melanocytes is sufficient to induce 
melanoma development in mice in vivo with $100 \%$ penetrance in the absence of any additional known exogenous carcinogens (Pollock et al., 2003; Wall et al., 2013).

Further studies demonstrated that constitutive expression of mGluR1 is required to maintain the transformed phenotype in vitro and in vivo. Using an inducible mouse model, Ohtani et al., showed that conditionally induced mGluR 1 expression stimulated melanocyte growth leading to melanoma, while silencing mGluR1 expression resulted in tumor abrogation in vivo (Ohtani et al., 2008). In melanomas, stimulation of mGluR1 by glutamate results in near-identical formation of second messengers as previously described for the CNS. Through the second messenger, DAG, PKC is stimulated resulting in activation of the RASRAF-MEK-ERK module of the MAPK signaling cascade and the PI3K/AKT pathway, thus up-regulating cell proliferation and inhibiting apoptosis (Busca et al., 2000; Choe and Wang, 2002; Ferraguti et al., 1999; Marin and Chen, 2004; Marin et al., 2006; Thandi et al., 2002).

Furthermore, we demonstrated elevated levels of extracellular glutamate only in mGluR1expressing melanoma cells, suggesting the existence of autocrine loops, a characteristic of oncogenic GPCRs (Gutkind et al., 1991; Julius et al., 1989; Namkoong et al., 2007). We also demonstrated that MAPK is a downstream target of mGluR1 signaling. Receptor stimulation with the agonist L-quisqualate resulted in increased levels of phosphorylated ERK, indicating active MAPK downstream signaling. Pretreatment of melanoma cells with mGluR1 antagonist, LY367385, followed by agonist treatment did not activate the MAPK pathway suggesting that MAPK activation is dependent upon functional mGluR1 (Namkoong et al., 2007). Other groups have shown that approximately $80 \%$ of melanoma tissue samples including 33\% of common, blue and Spitz nevi, $75 \%$ of human melanoma cell lines, and $50 \%$ of nevus lines are mGluR1-positive, while normal melanocytes are mGluR1-negative (Funasaka et al., 1996). These findings point to mGluR1 involvement in the oncogenesis of a subset of human melanomas (Namkoong et al., 2007; Pollock et al., 2003).

Additional recent studies from Gelb and colleagues confirm that mGluR1 expression in melanoma cells confers glutamate dependence for cell viability and DNA synthesis in human melanoma cells SK-MEL-2 and SK-MEL-5. Using both shRNA against mGluR1 and a non-competitive mGluR1 antagonist that had previously never been used in an oncologic setting, JNJ16259685, downregulation of mGluR1-expression decreased cell viability of human melanoma cells in vitro and tumor growth in vivo in a xenograft model (Gelb et al., 2015b). Other new experiments demonstrate that other pathways in addition to MAPK likely mediate mGluR1-mediated cell viability in melanoma cells. They showed that the mGluR1 agonist quisqualate does not always modulate phosphoinositol hydrolysis and promote cell viability as does the native ligand glutamate, indicating that future studies of melanoma cell viability in mGluR1-positive cell lines should not use agonists synonymously with glutamate for stimulation studies. In addition, a novel mGluR1-mediated but G-protein independent signaling cascade involving dynamin was found to upregulate MAPK signaling with sustained phosphorylation of ERK. A dynamin inhibitor, dynasore, dose-dependently decreased glutamate dependent cell viability of mGluR1-positive human melanoma cells SK-MEL-2 and SK-MEL-5, but had no effect on viability in mGluR1-negative human melanoma cells UACC930. These results suggest that internalization of mGluR1 receptors 
via dynamin activity may play an additional role in the cell viability of a subset of mGluR-1 positive melanomas (Gelb et al., 2015a).

\section{mGluR1 as a therapeutic target in treating melanoma}

Results from cultured cell studies suggest that ectopic expression of mGluR1 in cells led to the establishment of autocrine loop with high levels of extracellular glutamate to ensure constitutive activated receptor and up-regulated glutamate signaling to participate in neoplastic transformation in vitro and tumorigenesis in vivo. Because decreasing the levels of available glutamate would most likely dampen the glutamatergic signaling and reduce the oncogenic activity of mGluR1. We tested this notion by using riluzole, an inhibitor of glutamate release, in mGluR1-expressing melanoma cells.

Riluzole, marketed by Sanofi-Aventis as Rilutek $®$, is classified as an anti-excitotoxic, neuroprotective drug that blocks cellular release of glutamate. It is FDA-approved for the treatment of amyotrophic lateral sclerosis (ALS). Riluzole has an absolute bioavailability of approximately $60 \%$, which is relatively high, and is also able to cross the blood-brain barrier. Its mechanism of glutamate blockade is thought to be in part due to inactivation of voltage-gated sodium channels on glutamatergic nerve terminals and/or activation of a Gprotein dependent signaling cascade (Doble, 1996). Similarly, riluzole has also been shown to block some postsynaptic glutamatergic effects by noncompetitive inhibition of NMDA receptors (Doble, 1996).

In vitro riluzole treatment of mGluR1-expressing human melanoma cells reduces cell proliferation and decreases levels of extracellular glutamate, functionally much like the mGluR1 antagonists LY367385 and BAY36-7620 (Figure 2). In vivo human melanoma cell xenograft studies also showed a 50\% inhibition of tumor growth compared to controls.

Furthermore, cell cycle analysis on riluzole-treated mGluR1-expressing human melanoma cells showed accumulation in the G2-M phase and subsequent buildup in the sub-G1 phase of the cell cycle, consistent with apoptosis, which was confirmed in Westerns with elevated cleaved PARP, an apoptosis marker (Namkoong et al., 2007).

Results from these preclinical studies prompted us to translate into the clinic with a phase 0 , first-in-human trial using riluzole in stage III and IV melanoma patients (Yip et al., 2009). The drug was well tolerated and yielded an unexpected significant short-term response rate in 34\% of patients. The tumors that shrank in human subjects showed an inhibition of signaling through both the MAPK and PI3K/AKT pathways, correlating with results from preclinical studies (Namkoong et al., 2007; Yip et al., 2009). Additionally, Positron Emission Tomography (PET) documented complete resolution of multiple nodal and cutaneous metastases in several patients. Out of eleven patients that completed the study, only two had disease progression post-treatment. While all patients were positive for mGluR1 expression, the tumor samples also harbored a composite of most common mutations in melanoma, including BRAF V600E as well as NRAS Q61K. From this observation, a possible corollary is that more advanced tumors, as in those found in stage III and IV metastases, have a higher frequency of ectopic mGluR1 expression. A Phase 2 trial

Neuropharmacology. Author manuscript; available in PMC 2018 March 15. 
of riluzole as a single agent for melanoma treatment yielded similar results, with initial stable disease in $30 \%$ of patients (Mehnert et al., 2013).

Although radiosensitizers have previously not been shown to provide survival benefit in human melanoma, Khan and colleagues (Khan et al., 2011) hypothesized that riluzole may be different, as cells in the G2/M phase rendered by riluzole treatment would be extremely sensitive to radiation (Ballo and Ang, 2004; Ballo et al., 2006; Eichler et al., 2007; Habermalz and Fischer, 1976). In vitro studies showed that mGluR1-positive human melanoma cells were significantly less likely to survive following ionizing radiation treatment at the 2 and $4 \mathrm{~Gy}$ dose levels when pre-treated with riluzole at $25 \mu \mathrm{M}$ concentration, while there was negligible effect in mGluR1- negative human melanoma cells even at $100 \mu \mathrm{M}$ of riluzole treatment. Furthermore, riluzole with irradiation in mGluR1-positive human melanoma cells induced G2/M synchronization in a sequence-dependent manner, and rendering the receptor non-functional with the non-competitive antagonist of mGluR1, BAY36-7620, prior to riluzole treatment abrogated these effects. These findings reveal that the mechanism of riluzole is more complex than merely diminish available glutamate. In vivo, mGluR1- positive human melanoma xenografts treated with riluzole plus irradiation resulted in smaller tumor volume and significant increase in apoptotic tumor cells that stained positive for cleaved caspase-3, a marker of apoptosis, and $\gamma-\mathrm{H} 2 \mathrm{AX}$ foci, a marker of DNA-double stranded breaks (Khan et al., 2011). These results suggest that riluzole may be used as a radiosensitizer in a subset of mGluR1 expressing human melanomas.

Further research led to the unexpected discovery that riluzole by itself led to DNA damage and that riluzole in association with irradiation produced additive DNA double-strand breaks in mGluR1-postive human melanoma cells in vitro and in vivo, as evident by the histological detection of $\gamma-\mathrm{H} 2 \mathrm{AX}$ foci and phosphorylation of histone H2AX on Western immunoblots (Wall et al., 2014). These findings only manifest in mGluR1-positive human melanoma cells but not mGluR1-negative cells. Additional experiments showed co-localization of both $\gamma$ $\mathrm{H} 2 \mathrm{AX}$ and 53BP1. 53BP1, a checkpoint regulator that binds to $\mathrm{p} 53$ and translocates to sites of DNA breaks in response to DNA damage (Wall et al., 2015). Similar results were observed in isogenic vector control or mGluR1 clones derived from immortalized, nontumorigenic human melanocytes (Wall et al., 2014).

Using a genetic inducible siRNA (si-GRM1) approach in C8161 human melanoma cells, DNA damage was reduced in riluzole-treated induced si-GRM1 clones, compared to the same clones not subject to the induction of si-GRM1 (Wall et al., 2014). These results support mGluR1-dependent riluzole-mediated DNA damage as the mode of action. In the same report, we proposed that in the presence of riluzole, synthesis of the antioxidant glutathione (GSH), may be interrupted by increased intracellular glutamate that could disrupt the bidirectional transport of glutamate and cysteine required for GSH synthesis (Wall et al., 2014). A decrease in GSH causes increased oxidative stress and reactive oxygen species (ROS) detectible by the ROS-specific marker dihydrorhodamine 123 (DHR123). We confirmed an increase in ROS only in riluzole-treated mGluR1-positive cells but not mGluR1-negative cells (Wall et al., 2014). We also retroactively assessed pre- and posttreatment specimens from the phase 0 and 2 clinical trials of riluzole for DNA damage. A significant number of $\gamma-\mathrm{H} 2 \mathrm{AX}$ staining cells in post-treatment samples of stable disease 
patients with biologic responses compared to pre-treatment samples from the same patients were observed. In comparison, samples from non-responding patients with disease progression showed low and similar numbers of $\gamma-\mathrm{H} 2 \mathrm{AX}$ foci in pre- and post-treatment specimens (Mehnert et al., 2013; Wall et al., 2014; Yip et al., 2009).

As melanoma is a heterogenous disease and clinical trials utilizing riluzole have shown positive response in only a subset of mGluR1-positive melanomas, we suspect involvement and even crosstalk with other pathways. We showed with mouse melanoma cells that IGF-1R transactivation is involved in mGluR1-mediated melanocyte transformation (Teh et al., 2014) mGluR1 receptor functionality was assessed with the mGluR1 agonist, Lquisqualate [Q], in stable mGluR1-clones derived from a normal mouse melanocytic cell line. AKT activation was observed, but the addition of an IGF-1R inhibitor, PPP, resulted in lack of alterations in AKT activity above baseline, even in the presence of mGluR1-agonist Q, suggesting that functional IGF-1R is necessary for mGluR1-mediated stimulation of the AKT cascade (Shin et al., 2008; Teh et al., 2014). Treatment of human melanoma cells with riluzole and OSI- 906, a potent inhibitor of IGF-1R, suppressed cell growth more than either agent alone (Fassnacht et al., 2011; Mulvihill et al., 2009; Teh et al., 2014; Zhao et al., 2012). This synergistic response was reproducible in an in vivo xenograft model, suggesting that IGF signaling is involved in crosstalk with mGluR1 in human melanoma. To validate this hypothesis, we again turned to tumor biopsies from five patients with advanced metastatic melanoma treated with monotherapy riluzole from the completed phase 0 and 2 trials. Notably, responders showed decreased phospho-IGF- 1R and phospho-AKT levels, and non-responders showed increased phospho-IGF-1R and phospho-AKT. While limited by sample size, these results point to a role of the IGF-1R/AKT pathway in single agent riluzole response in melanoma patients (Teh et al., 2014). Additionally, simultaneous targeting of both MAPK and PI3K signaling pathways in human melanoma brain metastasis-derived cells in vitro can decrease cell survival and invasion (Daphu et al., 2014). As mGluR1 affects both MAPK and PI3K, therapies like riluzole may play a role in overcoming resistance that develops after targeted MAPK and PI3K inhibitor treatment.

Our laboratory has also studied the inhibitors sorafenib or PLX4720/PLX4032 in combination with riluzole. Sorafenib is a small-molecule, multi-kinase inhibitor, and PLX4720/PLX4032 is a small molecule inhibitor specific to mutated BRAF V600E kinase. We showed that mGluR1-positive cells containing a BRAF V600E mutation were less sensitive to riluzole because both mGluR1 and BRAF V600E stimulate MAPK signaling (Lee et al., 2011a). Furthermore, using a combination of riluzole and sorafenib synergistically reduces growth of wild type or BRAF V600E human melanoma cells in vitro and in vivo and the combination of riluzole and PLX4720/PLX4032 also has additive effects on the suppression of melanoma cell growth (Lee et al., 2011b). These results have been formulated into an ongoing Phase I clinical trial to assess the safety and efficacy of riluzole with sorafenib in stage III/IV melanoma patients.

\section{mGluR1 in brain metastasis}

Excessive glutamate induces excitotoxicity in surrounding neuronal tissue, and in brain tumors this creates space for the expansion of the growing tumor (Van den Bosch, 2006; Yu 
et al., 2015). Melanoma is one of the most common cancers metastasizing to the brain after lung and breast carcinomas, interesting, as melanocytes originate from the neural crest. Recently, our group reviewed brain metastasis from melanoma and current treatments (Yu et al., 2015). In short, these metastases tend to be small, multiple, and hemorrhagic (Chaichana and Chaichana, 2011; Ewend et al., 1996; Graus et al., 1985; Wronski and Arbit, 2000). Treatment modalities include anti-epileptic drugs for symptomatic relief versus definitive treatment with surgical resection, whole brain radiation treatment, stereotactic radiosurgery, targeted therapies, immunotherapies, or a combination of the above (Yu et al., 2015). However, there remains a dearth of effective treatment options for melanoma brain metastasis. Radiation is still one of the mainstays of treatment for primary brain tumors and brain metastases, but efficacy in metastases from melanoma is low compared to that from other primary tumor types (Habermalz and Fischer, 1976; McKay and Kefford, 1995;

Nicholas et al., 2013). Among cancers that commonly metastasize to the brain, lung cancers, especially small cell lung carcinomas, are most susceptible to radiation, while breast cancers are less sensitive; melanoma and renal cell carcinomas are least sensitive (Barranco et al., 1971).

mGluRs, including those in group I and group II, have been shown to be involved in brain specific metastasis and proliferation of melanoma. Nygaard and colleagues have shown that a brain-adaptive phenotype of melanoma is found prominently in early metastatic growth phases and occurs via activation of the glutamate receptor mediated $\mathrm{Ca}^{2+}$-dependent signaling that regulates transcription and neuron-like plasticity (Nygaard et al., 2014). They also reported that elevated levels of extracellular glutamate was detected in the conditioned medium of the MM1 melanoma cells after 72 hours in culture; these cells are not as proliferative but more invasive when compared to the MM5 melanoma cell line, which is rapidly proliferating, but noninvasive (Nygaard et al., 2014). Further studies showed that blockade of upregulated glutamate receptors GRIA1, GRIA2, mGluR3 and mGluR4 by specific antagonists decreased cell viability, establishing a system of functional glutamate signaling in these cells in vitro (Nygaard et al., 2014).

Incidentally, we also speculate that melanoma is one of the most common primary tumors that lead to hemorrhagic intracranial metastases (Lieu et al., 1999; Mandybur et al., 1977). Goydos and colleagues recently showed that melanoma cells with enhanced mGluR1 expression produced not only large tumors in vivo, but also more vascular tumors than their lower mGluR1-expressing counterparts. Cultured mGluR1-positive human melanoma cells produced more interleukin-8 (IL-8) and VEGF likely via mGluR1-mediated activation of the AKT-mTOR-HIF1 pathway. Moreover, in clinical post-treatment specimens from patients treated with single agent riluzole not only showed inhibition of MAPK and PI3K/AKT activities, but also decreased density of blood vessels, indicating that suppression of glutamate signaling downstream from mGluR1 could promote anti-angiogenic effects, suggesting inhibition of mGluR1 as a potential target in treatment of melanoma and other cancers with high likelihood of hemorrhagic brain metastases, including renal cell carcinoma (RCC) and hepatocellular carcinoma (HCC) (Lieu et al., 1999; Ti, 1977; Wen et al., 2014). 
Recently, our laboratory utilized orthotopically-implanted mGluR1 expressing human melanoma xenografts in mice as a model for intracranial melanoma metastases. Based on preclinical studies and riluzole's ability to cross the blood-brain barrier, we predicted that riluzole would elicit anti-proliferative effects on human melanoma cells in the brain, and would act cooperatively with ionizing radiation therapy. We used a bioluminescence enzyme firefly luciferase (Fluc) reporter introduced into the mGluR1-positive human melanoma cell line C8161 to produce several stable clones (C8161-luc), creating a monitoring approach using IVIS, a small animal imaging system for in vivo assessment of tumor burden without having to sacrifice animals at different time intervals. Intraperitoneal (IP) injection of luciferin substrate into animals allowed for oxidation by luciferase, resulting in photon emission/bioluminescence signal intensity acquisition and quantification by IVIS. These signal intensities were first demonstrated to correlate with tumor volume measured by a Vernier caliper in a xenograft tumor experiment using C8161-luc cells injected into the dorsal flanks of athymic nude mice. To model brain metastases, we injected C8161-luc cells intracranially into a new set of mice and monitored for tumor establishment using luminescent imaging. Following tumor detection, the mice were randomized into four treatment groups: vehicle (Veh, DMSO), vehicle and a weekly dose of 4 Gy irradiation (IR), riluzole daily via oral gavage (Ril), and a combination of irradiation and riluzole (Ril+IR). We showed that riluzole or irradiation alone was able to reduce melanoma tumor cell growth in the brain over time as compared to vehicle-treatment. However, combination treatment of Ril+IR yielded even smaller tumor burden as demonstrated by the decreased luminescent signal after four weeks of treatment compared with vehicle-treated or either treatment modality alone (Korangath et al., 2015). From these results, we propose that riluzole could be used as a radiosensitizer for the treatment of intracranial metastasis in combination with irradiation in mGluR1-positive human melanomas (Yu et al., 2015).

\section{mGluR1 in breast cancer}

mGluR1 expression has been widely explored in breast cancer. Speyer et al., reported the expression of mGluR1 in five triple negative breast cancer (TNBC) cell lines, as well as normal mammary epithelial cells with varied expression levels. Silencing of the receptor with GRM1 shRNA resulted in inhibition of cell proliferation. Pharmacologically, treatment of mGluR1-expressing TNBC cell lines with riluzole, decreased the available ligand to sustain the activated receptor, therefore functioning as an antagonist. In a series of in vitro and in vivo experiments, inclusion of riluzole in the growing media or administration via oral gavage to xenograft tumor-bearing mice resulted in reduced cell proliferation, tumor progression, and induced apoptosis in vitro and in vivo (Speyer et al., 2012). Additionally, isogenic breast cancer cell lines constructed to mirror the progression of breast cancer demonstrate higher expression of mGluR1 mRNA and protein in premalignant and malignant cells than in normal mammary epithelial cells (Banda et al., 2014). Interestingly, lentiviral mediated overexpression of mGluR1 in premalignant MCF10A cells showed no significant effects on proliferation, invasion, or soft agar colony formation in vitro, suggesting that the receptor may be involved in later steps during progression. To evaluate this hypothesis, mGluR1 was overexpressed in MCF10AT1 cells, which represent atypical ductal hyperplasia. In this case, a significant increase in the proliferation of the cells was 
observed. Inhibition of receptor activity using the non-competitive antagonist, BAY36-7620, or GRM1 shRNA negatively impacted proliferation. With these data, it was hypothesized that mGluR1 may also influence other oncogenic functions that support tumor growth. As such, investigation of the effects of mGluR1 on the migration and invasion of the cell lines was performed. Overexpression of mGluR1 in the MCF10AT1 atypical ductal hyperplasia cells resulted in increased migration and invasion through a reconstructed basement membrane as well as anchorage independent growth. These alterations were diminished when mGluR1 expression was disrupted using shRNA. In vivo, the mGluR1 overexpressing cells formed multiple invasive carcinomas compared to parental or vector control cells, suggesting a role for mGluR1 in malignant breast cancer phenotypes. Triple negative breast cancers identified by their lack of expression of progesterone, estrogen and Her2/Neu receptors, remain an important challenge in breast cancer management that impacts on thousands of women because this class of breast cancer does snot respond to targeted therapies. For this reason, identification of mGluR1 as a contributor to proliferation, invasion, and malignant progression in TNBC offers a potential therapeutic target.

In addition to the reported roles of mGluR1 in promoting cell proliferation, invasion, anchorage independent growth and in vivo carcinoma formation (Banda et al., 2014; Speyer et al., 2012), mGluR1 has also been linked in supporting angiogenesis in breast cancer (Speyer et al., 2014). In vitro studies using primary endothelial cells showed that cells expressing elevated levels of mGluR1 had greater sensitivity to BAY36-7620 and riluzole. Tube formation on matrigel, an ex vivo model of angiogenesis, was suppressed in cells treated with BAY36-7620 or riluzole, suggesting participation of mGluR1 in the angiogenic process. In an in vivo murine mammary tumor model with a strong vascular component, when treated with riluzole or Sunitinib (Roskoski, 2007), a similar inhibition in tumor growth was observed as earlier reports (Banda et al., 2014; Speyer et al., 2012), and a reduction in microvessel density was also demonstrated for riluzole at $60 \%$ and Sunitinib at $80 \%$, suggesting that mGluR1 may mediate its effect on tumor cell growth and invasion partly by enhancing angiogenesis.

While the contributions of mGluR1 overexpression in breast cancer were explored, a correlation between the polymorphic variants of GRM1 and breast cancer subtypes was demonstrated (Mehta et al., 2013). Earlier, in a genetic association study examining correlation of 3 single nucleotide polymorphisms in GRM1 and melanoma susceptibility showed higher frequency of one of the polymorphisms in GRM1-positive melanoma patients compared to controls. It was also reported that the frequency of this polymorphism was greater in subgroup of patients with low level of sun exposure and tumors located on the trunk and extremities (Ortiz et al., 2007). Mehta et al., examined GRM1 polymorphisms in breast cancer. Genotyping of over 1000 breast cancer specimens showed that 2 polymorphisms were associated with age at diagnosis and either estrogen or progesterone receptor positive disease. In vitro validation of these observations using estrogen and progesterone positive (MFC7) or TNBC (MDA-MB-231) cell lines treated with either 17 $\beta$ estradiol or with the combination of $17 \beta$-estradiol and progesterone assessed possible modulation in mGluR1 expression. In MCF7 cells, mGluR1 expression increased 2.7 fold after $17 \beta$-estradiol treatment and 2.1 -fold after $17 \beta$-estradiol plus progesterone treatment. These effects were blocked when the cells were pretreated with tamoxifen. mGluR1 
expression was not affected by $17 \beta$-estradiol and progesterone in the receptor negative MDA-MB-231 cells. This study also showed that estrogen receptor positive tumors were more likely to express mGluR1 in comparison to estrogen negative tumors. Additionally, it revealed that patients with low mGluR1 expressing tumors were associated with longer periods of distant metastasis-free survival as compared to those with higher mGluR1 expression. These results show that mGluR1 may not only be involved in the disease progression, but that it might also affect response to hormone based therapy in breast cancer. Given that mGluR1 appears to influence triple negative breast cancer, estrogen and progesterone positive subtypes, riluzole and other drugs that target this receptor might prove useful in a clinical setting.

\section{Conclusions}

Our knowledge of the functions of metabotropic glutamate receptors is constantly evolving. This evolution has changed the perception that these receptors are mainly involved in neuronal signaling, neurodevelopmental disorders and neuronal malignancies. A tremendous amount of work has emerged on the role of mGluRs in the biology of melanoma, breast, prostate cancers, and in tumors that originate in the brain or those that metastasize to the brain. The evidence for mGluR1 involvement in melanoma has led to the application of riluzole, a drug used to inhibit glutamate release in ALS, as an anti-melanoma drug and as a radiosensitizer that can be used to treat other tumors that involve mGluR1-mediated glutamate signaling that commonly metastasize to the brain. Further understanding of how other glutamate receptors affect human cancers, as well as development of other receptor modulators will result in multiple applications that extend far beyond the traditional roles associated with the glutamate receptors.

\section{References}

Ali S, Shourideh M, Koochekpour S. Identification of novel GRM1 mutations and single nucleotide polymorphisms in prostate cancer cell lines and tissues. PloS one. 2014; 9:e103204. [PubMed: 25062106]

Alix JJ, Domingues AM. White matter synapses: form, function, and dysfunction. Neurology. 2011; 76:397-404. [PubMed: 21263141]

Arcella A, Carpinelli G, Battaglia G, D’Onofrio M, Santoro F, Ngomba RT, Bruno V, Casolini P, Giangaspero F, Nicoletti F. Pharmacological blockade of group II metabotropic glutamate receptors reduces the growth of glioma cells in vivo. Neuro-oncology. 2005; 7:236-245. [PubMed: 16053698]

Aronica E, Gorter JA, Ijlst-Keizers H, Rozemuller AJ, Yankaya B, Leenstra S, Troost D. Expression and functional role of mGluR3 and mGluR5 in human astrocytes and glioma cells: opposite regulation of glutamate transporter proteins. The European journal of neuroscience. 2003; 17:21062118. [PubMed: 12786977]

Balazs R, Miller S, Romano C, de Vries A, Chun Y, Cotman CW. Metabotropic glutamate receptor mGluR5 in astrocytes: pharmacological properties and agonist regulation. Journal of neurochemistry. 1997; 69:151-163. [PubMed: 9202306]

Ballo MT, Ang KK. Radiotherapy for cutaneous malignant melanoma: rationale and indications. Oncology (Williston Park). 2004; 18:99-107. discussion 107-110, 113-104. [PubMed: 14768409]

Ballo MT, Ross MI, Cormier JN, Myers JN, Lee JE, Gershenwald JE, Hwu P, Zagars GK. Combinedmodality therapy for patients with regional nodal metastases from melanoma. Int J Radiat Oncol Biol Phys. 2006; 64:106-113. [PubMed: 16182463] 
Banda M, Speyer CL, Semma SN, Osuala KO, Kounalakis N, Torres Torres KE, Barnard NJ, Kim HJ, Sloane BF, Miller FR, Goydos JS, Gorski DH. Metabotropic glutamate receptor-1 contributes to progression in triple negative breast cancer. PloS one. 2014; 9:e81126. [PubMed: 24404125]

Barranco SC, Romsdahl MM, Humphrey RM. The radiation response of human malignant melanoma cells grown in vitro. Cancer Res. 1971; 31:830-833. [PubMed: 5088486]

Bhowmick NA, Neilson EG, Moses HL. Stromal fibroblasts in cancer initiation and progression. Nature. 2004; 432:332-337. [PubMed: 15549095]

Brocke KS, Staufner C, Luksch H, Geiger KD, Stepulak A, Marzahn J, Schackert G, Temme A, Ikonomidou C. Glutamate receptors in pediatric tumors of the central nervous system. Cancer biology \& therapy. 2010; 9:455-468. [PubMed: 20061814]

Burger M, Burger JA, Hoch RC, Oades Z, Takamori H, Schraufstatter IU. Point mutation causing constitutive signaling of CXCR2 leads to transforming activity similar to Kaposi's sarcoma herpesvirus-G protein-coupled receptor. J Immunol. 1999; 163:2017-2022. [PubMed: 10438939]

Busca R, Abbe P, Mantoux F, Aberdam E, Peyssonnaux C, Eychene A, Ortonne JP, Ballotti R. Ras mediates the cAMP-dependent activation of extracellular signal-regulated kinases (ERKs) in melanocytes. The EMBO journal. 2000; 19:2900-2910. [PubMed: 10856235]

Cairns RA, Harris IS, Mak TW. Regulation of cancer cell metabolism. Nature reviews Cancer. 2011; 11:85-95. [PubMed: 21258394]

Chaichana, KK., Chaichana, KL. Diagnosis and treatment options for brain metastasis of melanoma. In: Morton, MR., editor. Treatment of Metastatic Melanoma. InTech; 2011.

Chang HJ, Yoo BC, Lim SB, Jeong SY, Kim WH, Park JG. Metabotropic glutamate receptor 4 expression in colorectal carcinoma and its prognostic significance. Clin Cancer Res. 2005; 11:3288-3295. [PubMed: 15867225]

Chen S, Zhu H, Wetzel WJ, Philbert MA. Spontaneous melanocytosis in transgenic mice. J Invest Dermatol. 1996; 106:1145-1151. [PubMed: 8618055]

Cheng N, Chytil A, Shyr Y, Joly A, Moses HL. Transforming growth factor-beta signaling-deficient fibroblasts enhance hepatocyte growth factor signaling in mammary carcinoma cells to promote scattering and invasion. Molecular cancer research : MCR. 2008; 6:1521-1533. [PubMed: 18922968]

Choe ES, Wang JQ. Regulation of transcription factor phosphorylation by metabotropic glutamate receptor-associated signaling pathways in rat striatal neurons. Neuroscience. 2002; 114:557-565. [PubMed: 12220559]

Choi KY, Chang K, Pickel JM, Badger JD 2nd, Roche KW. Expression of the metabotropic glutamate receptor 5 (mGluR5) induces melanoma in transgenic mice. Proc Natl Acad Sci U S A. 2011; 108:15219-15224. [PubMed: 21896768]

Ciceroni C, Bonelli M, Mastrantoni E, Niccolini C, Laurenza M, Larocca LM, Pallini R, Traficante A, Spinsanti P, Ricci-Vitiani L, Arcella A, De Maria R, Nicoletti F, Battaglia G, Melchiorri D. Type-3 metabotropic glutamate receptors regulate chemoresistance in glioma stem cells, and their levels are inversely related to survival in patients with malignant gliomas. Cell death and differentiation. 2013; 20:396-407. [PubMed: 23175182]

D’Onofrio M, Arcella A, Bruno V, Ngomba RT, Battaglia G, Lombari V, Ragona G, Calogero A, Nicoletti F. Pharmacological blockade of mGlu2/3 metabotropic glutamate receptors reduces cell proliferation in cultured human glioma cells. Journal of neurochemistry. 2003; 84:1288-1295. [PubMed: 12614329]

Daphu I, Horn S, Stieber D, Varughese JK, Spriet E, Dale HA, Skaftnesmo KO, Bjerkvig R, Thorsen F. In vitro treatment of melanoma brain metastasis by simultaneously targeting the MAPK and PI3K signaling pathways. International journal of molecular sciences. 2014; 15:8773-8794. [PubMed: 24840574]

DeBerardinis RJ, Mancuso A, Daikhin E, Nissim I, Yudkoff M, Wehrli S, Thompson CB. Beyond aerobic glycolysis: transformed cells can engage in glutamine metabolism that exceeds the requirement for protein and nucleotide synthesis. Proc Natl Acad Sci U S A. 2007; 104:1934519350. [PubMed: 18032601]

Deberardinis RJ, Sayed N, Ditsworth D, Thompson CB. Brick by brick: metabolism and tumor cell growth. Current opinion in genetics \& development. 2008; 18:54-61. [PubMed: 18387799] 
Degenhardt K, White E. A mouse model system to genetically dissect the molecular mechanisms regulating tumorigenesis. Clin Cancer Res. 2006; 12:5298-5304. [PubMed: 17000662]

Dimski T, Heinen-Lauten J, Krep H. Basal tako-tsubo cardiomyopathy. Induction of a pheochromocytoma after general anesthesia. Anaesthesist. 2008; 57:143-146. [PubMed: 18038119]

Doble A. The pharmacology and mechanism of action of riluzole. Neurology. 1996; 47:S233-241. [PubMed: 8959995]

Eichler AF, Batchelor TT, Henson JW. Diffusion and perfusion imaging in subacute neurotoxicity following high-dose intravenous methotrexate. Neuro-oncology. 2007; 9:373-377. [PubMed: 17522329]

Esseltine JL, Ferguson SS. Regulation of G protein-coupled receptor trafficking and signaling by Rab GTPases. Small GTPases. 2013; 4:132-135. [PubMed: 23511852]

Estrela JM, Ortega A, Obrador E. Glutathione in cancer biology and therapy. Critical reviews in clinical laboratory sciences. 2006; 43:143-181. [PubMed: 16517421]

Ewend MG, Carey LA, Brem H. Treatment of melanoma metastases in the brain. Semin Surg Oncol. 1996; 12:429-435. [PubMed: 8914207]

Fairman WA, Amara SG. Functional diversity of excitatory amino acid transporters: ion channel and transport modes. The American journal of physiology. 1999; 277:F481-486. [PubMed: 10516269]

Fassnacht M, Libe R, Kroiss M, Allolio B. Adrenocortical carcinoma: a clinician's update. Nat Rev Endocrinol. 2011; 7:323-335. [PubMed: 21386792]

Fendt SM, Bell EL, Keibler MA, Olenchock BA, Mayers JR, Wasylenko TM, Vokes NI, Guarente L, Vander Heiden MG, Stephanopoulos G. Reductive glutamine metabolism is a function of the alpha-ketoglutarate to citrate ratio in cells. Nat Commun. 2013; 4:2236. [PubMed: 23900562]

Ferraguti F, Baldani-Guerra B, Corsi M, Nakanishi S, Corti C. Activation of the extracellular signalregulated kinase 2 by metabotropic glutamate receptors. The European journal of neuroscience. 1999; 11:2073-2082. [PubMed: 10336676]

Filipp FV, Ratnikov B, De Ingeniis J, Smith JW, Osterman AL, Scott DA. Glutamine-fueled mitochondrial metabolism is decoupled from glycolysis in melanoma. Pigment Cell Melanoma Res. 2012; 25:732-739. [PubMed: 22846158]

Funasaka Y, Harada T, Aiba A, Nishigori C. Expression of metabotropic glutamate receptor and phosphorylated extracellular signal-regulated kinase 1/2 proteins in human melanocytic lesions. Pigment cell research / sponsored by the European Society for Pigment Cell Research and the International Pigment Cell Society. 1996; 19:656.

Gaglio D, Soldati C, Vanoni M, Alberghina L, Chiaradonna F. Glutamine deprivation induces abortive s-phase rescued by deoxyribonucleotides in k-ras transformed fibroblasts. PloS one. 2009; 4:e4715. [PubMed: 19262748]

Gameiro PA, Yang J, Metelo AM, Perez-Carro R, Baker R, Wang Z, Arreola A, Rathmell WK, Olumi A, Lopez-Larrubia P, Stephanopoulos G, Iliopoulos O. In vivo HIF-mediated reductive carboxylation is regulated by citrate levels and sensitizes VHL-deficient cells to glutamine deprivation. Cell metabolism. 2013; 17:372-385. [PubMed: 23473032]

Gao P, Tchernyshyov I, Chang TC, Lee YS, Kita K, Ochi T, Zeller KI, De Marzo AM, Van Eyk JE, Mendell JT, Dang CV. c-Myc suppression of miR-23a/b enhances mitochondrial glutaminase expression and glutamine metabolism. Nature. 2009; 458:762-765. [PubMed: 19219026]

Gelb T, Pshenichkin S, Hathaway HA, Grajkowska E, Dalley CB, Wolfe BB, Wroblewski JT. Atypical signaling of metabotropic glutamate receptor 1 in human melanoma cells. Biochemical pharmacology. 2015a; 98:182-189. [PubMed: 26291396]

Gelb T, Pshenichkin S, Rodriguez OC, Hathaway HA, Grajkowska E, DiRaddo JO, Wroblewska B, Yasuda RP, Albanese C, Wolfe BB, Wroblewski JT. Metabotropic glutamate receptor 1 acts as a dependence receptor creating a requirement for glutamate to sustain the viability and growth of human melanomas. Oncogene. 2015b; 34:2711-2720. [PubMed: 25065592]

Graus F, Rogers LR, Posner JB. Cerebrovascular complications in patients with cancer. Medicine (Baltimore). 1985; 64:16-35. [PubMed: 3965856] 
Gutkind JS, Novotny EA, Brann MR, Robbins KC. Muscarinic acetylcholine receptor subtypes as agonist-dependent oncogenes. Proc Natl Acad Sci U S A. 1991; 88:4703-4707. [PubMed: 1905013]

Habermalz HJ, Fischer JJ. Radiation therapy of malignant melanoma: experience with high individual treatment doses. Cancer. 1976; 38:2258-2262. [PubMed: 1000466]

Iacovelli L, Arcella A, Battaglia G, Pazzaglia S, Aronica E, Spinsanti P, Caruso A, De Smaele E, Saran A, Gulino A, D'Onofrio M, Giangaspero F, Nicoletti F. Pharmacological activation of mGlu4 metabotropic glutamate receptors inhibits the growth of medulloblastomas. The Journal of neuroscience : the official journal of the Society for Neuroscience. 2006; 26:8388-8397. [PubMed: 16899734]

Julius D, Livelli TJ, Jessell TM, Axel R. Ectopic expression of the serotonin 1c receptor and the triggering of malignant transformation. Science. 1989; 244:1057-1062. [PubMed: 2727693]

Karakas E, Regan MC, Furukawa H. Emerging structural insights into the function of ionotropic glutamate receptors. Trends in biochemical sciences. 2015; 40:328-337. [PubMed: 25941168]

Kelly A, Stanley CA. Disorders of glutamate metabolism. Ment Retard Dev Disabil Res Rev. 2001; 7:287-295. [PubMed: 11754524]

Khan AJ, Wall B, Ahlawat S, Green C, Schiff D, Mehnert JM, Goydos JS, Chen S, Haffty BG. Riluzole enhances ionizing radiation-induced cytotoxicity in human melanoma cells that ectopically express metabotropic glutamate receptor 1 in vitro and in vivo. Clin Cancer Res. 2011; 17:1807-1814. [PubMed: 21325066]

Koochekpour S. Glutamate, a metabolic biomarker of aggressiveness and a potential therapeutic target for prostate cancer. Asian journal of andrology. 2013; 15:212-213. [PubMed: 23314660]

Korangath P, Teo WW, Sadik H, Han L, Mori N, Huijts CM, Wildes F, Bharti S, Zhang Z, Santa-Maria CA, Tsai H, Dang CV, Stearns V, Bhujwalla ZM, Sukumar S. Targeting Glutamine Metabolism in Breast Cancer with Aminooxyacetate. Clin Cancer Res. 2015; 21:3263-3273. [PubMed: 25813021]

Kuribayashi N, Uchida D, Kinouchi M, Takamaru N, Tamatani T, Nagai H, Miyamoto Y. The role of metabotropic glutamate receptor 5 on the stromal cell-derived factor-1/CXCR4 system in oral cancer. PloS one. 2013; 8:e80773. [PubMed: 24236200]

Lee HJ, Wall BA, Wangari-Talbot J, Shin SS, Rosenberg S, Chan JL, Namkoong J, Goydos JS, Chen S. Glutamatergic pathway targeting in melanoma: single-agent and combinatorial therapies. Clin Cancer Res. 2011a; 17:7080-7092. [PubMed: 21844014]

Lee J, Yang EJ, Shin JS, Kim DH, Lee SS, Choi IH. CKD-712, (S)-1- (alpha-naphthylmethyl)-6,7dihydroxy-1,2,3,4-tetrahydroisoquinoline, Inhibits the NF-kappaB Activation and Augments Akt Activation during TLR4 Signaling. Immune network. 2011b; 11:420-423. [PubMed: 22346785]

Li L, Homan KT, Vishnivetskiy SA, Manglik A, Tesmer JJ, Gurevich VV, Gurevich EV. G Proteincoupled Receptor Kinases of the GRK4 Protein Subfamily Phosphorylate Inactive G Proteincoupled Receptors (GPCRs). J Biol Chem. 2015; 290:10775-10790. [PubMed: 25770216]

Lieu AS, Hwang SL, Howng SL, Chai CY. Brain tumors with hemorrhage. J Formos Med Assoc. 1999; 98:365-367. [PubMed: 10420706]

Mandybur TI, Nagpaul AS, Pappas Z, Niklowitz WJ. Alzheimer neurofibrillary change in subacute sclerosing panencephalitis. Annals of neurology. 1977; 1:103-107. [PubMed: 889286]

Marie SK, Shinjo SM. Metabolism and brain cancer. Clinics (Sao Paulo). 2011; 66(Suppl 1):33-43. [PubMed: 21779721]

Marin YE, Chen S. Involvement of metabotropic glutamate receptor 1, a G protein coupled receptor, in melanoma development. J Mol Med (Berl). 2004; 82:735-749. [PubMed: 15322701]

Marin YE, Namkoong J, Cohen-Solal K, Shin SS, Martino JJ, Oka M, Chen S. Stimulation of oncogenic metabotropic glutamate receptor 1 in melanoma cells activates ERK1/2 via PKCepsilon. Cellular signalling. 2006; 18:1279-1286. [PubMed: 16305822]

Martino JJ, Wall BA, Mastrantoni E, Wilimczyk BJ, La Cava SN, Degenhardt K, White E, Chen S. Metabotropic glutamate receptor $1(\mathrm{Grm} 1)$ is an oncogene in epithelial cells. Oncogene. 2013; 32:4366-4376. [PubMed: 23085756] 
McKay MJ, Kefford RF. The spectrum of in vitro radiosensitivity in four human melanoma cell lines is not accounted for by differential induction or rejoining of DNA double strand breaks. Int J Radiat Oncol Biol Phys. 1995; 31:345-352. [PubMed: 7836088]

Mehnert JM, Wen Y, Lee JH, Jeong BS, Li J, Dudek, Pruski-Clark L, LKMM, Lin H, Shih W, Chen S, Goydos JS. A phase II trial of riluzole, an antagonist of metabotropic glutamate receptor 1 (GRM1) signaling, in patients with advanced melanoma. 2013

Mehta MS, Dolfi SC, Bronfenbrener R, Bilal E, Chen C, Moore D, Lin Y, Rahim H, Aisner S, Kersellius RD, Teh J, Chen S, Toppmeyer DL, Medina DJ, Ganesan S, Vazquez A, Hirshfield KM. Metabotropic glutamate receptor 1 expression and its polymorphic variants associate with breast cancer phenotypes. PloS one. 2013; 8:e69851. [PubMed: 23922822]

Miller RG. Carrell-Krusen Symposium invited lecture. Clinical trials in motor neuron diseases. Journal of child neurology. 1999; 14:173-179. [PubMed: 10190269]

Moreadith RW, Lehninger AL. The pathways of glutamate and glutamine oxidation by tumor cell mitochondria. Role of mitochondrial NAD(P)+-dependent malic enzyme. J Biol Chem. 1984; 259:6215-6221. [PubMed: 6144677]

Mulvihill MJ, Cooke A, Rosenfeld-Franklin M, Buck E, Foreman K, Landfair D, O’Connor M, Pirritt C, Sun Y, Yao Y, Arnold LD, Gibson NW, Ji QS. Discovery of OSI-906: a selective and orally efficacious dual inhibitor of the IGF-1 receptor and insulin receptor. Future Med Chem. 2009; 1:1153-1171. [PubMed: 21425998]

Naarala J, Nykvist P, Tuomala M, Savolainen K. Excitatory amino acid-induced slow biphasic responses of free intracellular calcium in human neuroblastoma cells. FEBS letters. 1993; 330:222-226. [PubMed: 7689986]

Namkoong J, Shin SS, Lee HJ, Marin YE, Wall BA, Goydos JS, Chen S. Metabotropic glutamate receptor 1 and glutamate signaling in human melanoma. Cancer Res. 2007; 67:2298-2305. [PubMed: 17332361]

Nicholas S, Mathios D, Jackson C, Lim M. Metastatic melanoma to the brain: surgery and radiation is still the standard of care. Curr Treat Options Oncol. 2013; 14:264-279. [PubMed: 23504304]

Niklas J, Heinzle E. Metabolic flux analysis in systems biology of mammalian cells. Adv Biochem Eng Biotechnol. 2012; 127:109-132. [PubMed: 21432052]

Nygaard V, Prasmickaite L, Vasiliauskaite K, Clancy T, Hovig E. Melanoma brain colonization involves the emergence of a brain-adaptive phenotype. Oncoscience. 2014; 1:82-94. [PubMed: 25593989]

Ohtani Y, Harada T, Funasaka Y, Nakao K, Takahara C, Abdel-Daim M, Sakai N, Saito N, Nishigori C, Aiba A. Metabotropic glutamate receptor subtype-1 is essential for in vivo growth of melanoma. Oncogene. 2008; 27:7162-7170. [PubMed: 18776920]

Ortiz P, Vanaclocha F, Lopez-Bran E, Esquivias JI, Lopez-Estebaranz JL, Martin-Gonzalez M, Arrue I, Garcia-Romero D, Ochoa C, Gonzalez-Perez A, Ruiz A, Real LM. Genetic analysis of the GRM1 gene in human melanoma susceptibility. European journal of human genetics : EJHG. 2007; 15:1176-1182. [PubMed: 17609672]

Park SY, Lee SA, Han IH, Yoo BC, Lee SH, Park JY, Cha IH, Kim J, Choi SW. Clinical significance of metabotropic glutamate receptor 5 expression in oral squamous cell carcinoma. Oncology reports. 2007; 17:81-87. [PubMed: 17143482]

Petralia RS, Wang YX, Niedzielski AS, Wenthold RJ. The metabotropic glutamate receptors, mGluR2 and mGluR3, show unique postsynaptic, presynaptic and glial localizations. Neuroscience. 1996; 71:949-976. [PubMed: 8684625]

Pissimissis N, Papageorgiou E, Lembessis P, Armakolas A, Koutsilieris M. The glutamatergic system expression in human PC-3 and LNCaP prostate cancer cells. Anticancer research. 2009; 29:371377. [PubMed: 19331175]

Pollock PM, Cohen-Solal K, Sood R, Namkoong J, Martino JJ, Koganti A, Zhu H, Robbins C, Makalowska I, Shin SS, Marin Y, Roberts KG, Yudt LM, Chen A, Cheng J, Incao A, Pinkett HW, Graham CL, Dunn K, Crespo-Carbone SM, Mackason KR, Ryan KB, Sinsimer D, Goydos J, Reuhl KR, Eckhaus M, Meltzer PS, Pavan WJ, Trent JM, Chen S. Melanoma mouse model implicates metabotropic glutamate signaling in melanocytic neoplasia. Nat Genet. 2003; 34:108112. [PubMed: 12704387] 
Prickett TD, Samuels Y. Molecular pathways: dysregulated glutamatergic signaling pathways in cancer. Clin Cancer Res. 2012; 18:4240-4246. [PubMed: 22648273]

Prickett TD, Wei X, Cardenas-Navia I, Teer JK, Lin JC, Walia V, Gartner J, Jiang J, Cherukuri PF, Molinolo A, Davies MA, Gershenwald JE, Stemke-Hale K, Rosenberg SA, Margulies EH, Samuels Y. Exon capture analysis of $\mathrm{G}$ protein-coupled receptors identifies activating mutations in GRM3 in melanoma. Nat Genet. 2011; 43:1119-1126. [PubMed: 21946352]

Ribeiro FM, Paquet M, Cregan SP, Ferguson SS. Group I metabotropic glutamate receptor signalling and its implication in neurological disease. CNS Neurol Disord Drug Targets. 2010; 9:574-595. [PubMed: 20632969]

Roskoski R Jr. Sunitinib: a VEGF and PDGF receptor protein kinase and angiogenesis inhibitor. Biochem Biophys Res Commun. 2007; 356:323-328. [PubMed: 17367763]

Savage SA, Mirabello L, Wang Z, Gastier-Foster JM, Gorlick R, Khanna C, Flanagan AM, Tirabosco R, Andrulis IL, Wunder JS, Gokgoz N, Patino-Garcia A, Sierrasesumaga L, Lecanda F, Kurucu N, Ilhan IE, Sari N, Serra M, Hattinger C, Picci P, Spector LG, Barkauskas DA, Marina N, de Toledo SR, Petrilli AS, Amary MF, Halai D, Thomas DM, Douglass C, Meltzer PS, Jacobs K, Chung CC, Berndt SI, Purdue MP, Caporaso NE, Tucker M, Rothman N, Landi MT, Silverman DT, Kraft P, Hunter DJ, Malats N, Kogevinas M, Wacholder S, Troisi R, Helman L, Fraumeni JF Jr, Yeager M, Hoover RN, Chanock SJ. Genome-wide association study identifies two susceptibility loci for osteosarcoma. Nat Genet. 2013; 45:799-803. [PubMed: 23727862]

Shin SS, Namkoong J, Wall BA, Gleason R, Lee HJ, Chen S. Oncogenic activities of metabotropic glutamate receptor 1 (Grm1) in melanocyte transformation. Pigment Cell Melanoma Res. 2008; 21:368-378. [PubMed: 18435704]

Spanaki C, Plaitakis A. The role of glutamate dehydrogenase in mammalian ammonia metabolism. Neurotoxicity research. 2012; 21:117-127. [PubMed: 22038055]

Speyer CL, Hachem AH, Assi AA, Johnson JS, DeVries JA, Gorski DH. Metabotropic glutamate receptor-1 as a novel target for the antiangiogenic treatment of breast cancer. PloS one. 2014; 9:e88830. [PubMed: 24633367]

Speyer CL, Smith JS, Banda M, DeVries JA, Mekani T, Gorski DH. Metabotropic glutamate receptor-1: a potential therapeutic target for the treatment of breast cancer. Breast cancer research and treatment. 2012; 132:565-573. [PubMed: 21681448]

Stepulak A, Luksch H, Gebhardt C, Uckermann O, Marzahn J, Sifringer M, Rzeski W, Staufner C, Brocke KS, Turski L, Ikonomidou C. Expression of glutamate receptor subunits in human cancers. Histochem Cell Biol. 2009; 132:435-445. [PubMed: 19526364]

Stepulak A, Luksch H, Uckermann O, Sifringer M, Rzeski W, Polberg K, Kupisz K, Klatka J, Kielbus M, Grabarska A, Marzahn J, Turski L, Ikonomidou C. Glutamate receptors in laryngeal cancer cells. Anticancer research. 2011; 31:565-573. [PubMed: 21378340]

Sun RC, Denko NC. Hypoxic regulation of glutamine metabolism through HIF1 and SIAH2 supports lipid synthesis that is necessary for tumor growth. Cell metabolism. 2014; 19:285-292. [PubMed: 24506869]

Takano T, Lin JH, Arcuino G, Gao Q, Yang J, Nedergaard M. Glutamate release promotes growth of malignant gliomas. Nature medicine. 2001; 7:1010-1015.

Takayama H, LaRochelle WJ, Sharp R, Otsuka T, Kriebel P, Anver M, Aaronson SA, Merlino G. Diverse tumorigenesis associated with aberrant development in mice overexpressing hepatocyte growth factor/scatter factor. Proc Natl Acad Sci U S A. 1997; 94:701-706. [PubMed: 9012848]

Teh JL, Chen S. Glutamatergic signaling in cellular transformation. Pigment Cell Melanoma Res. 2012; 25:331-342. [PubMed: 22273393]

Teh JL, Shah R, Shin SS, Wen Y, Mehnert JM, Goydos J, Chen S. Metabotropic glutamate receptor 1 mediates melanocyte transformation via transactivation of insulin-like growth factor 1 receptor. Pigment Cell Melanoma Res. 2014; 27:621-629. [PubMed: 24628914]

Thandi S, Blank JL, Challiss RA. Group-I metabotropic glutamate receptors, mGlu1a and mGlu5a, couple to extracellular signal-regulated kinase (ERK) activation via distinct, but overlapping, signalling pathways. Journal of neurochemistry. 2002; 83:1139-1153. [PubMed: 12437585]

Ti TK. Advances in the surgical treatment of peptic ulcer. Med J Malaysia. 1977; 32:186-188. [PubMed: 614491] 
Van den Bosch L. The causes and mechanism of selective motor neuron death in amyotrophic lateral sclerosis. Verhandelingen - Koninklijke Academie voor Geneeskunde van Belgie. 2006; 68:249_ 269. [PubMed: 17214440]

Wall, BA., Shin, SS., Chen, S. Glutamate signaling in human cancers. In: Davids, LM., editor. Recent Advances in the BIology, Therapy and Management of Melanoma. InTech; 2013.

Wall BA, Wangari-Talbot J, Shin SS, Schiff D, Sierra J, Yu LJ, Khan A, Haffty B, Goydos JS, Chen S. Disruption of GRM1-mediated signalling using riluzole results in DNA damage in melanoma cells. Pigment Cell Melanoma Res. 2014; 27:263-274. [PubMed: 24330389]

Wall BA, Yu LJ, Khan A, Haffty B, Goydos JS, Chen S. Riluzole is a radio-sensitizing agent in an in vivo model of brain metastasis derived from GRM1 expressing human melanoma cells. Pigment Cell Melanoma Res. 2015; 28:105-109. [PubMed: 25363352]

Wen Y, Li J, Koo J, Shin SS, Lin Y, Jeong BS, Mehnert JM, Chen S, Cohen-Sola KA, Goydos JS. Activation of the glutamate receptor GRM1 enhances angiogenic signaling to drive melanoma progression. Cancer Res. 2014; 74:2499-2509. [PubMed: 24491800]

Willard SS, Koochekpour S. Glutamate, glutamate receptors, and downstream signaling pathways. International journal of biological sciences. 2013; 9:948-959. [PubMed: 24155668]

Wise DR, DeBerardinis RJ, Mancuso A, Sayed N, Zhang XY, Pfeiffer HK, Nissim I, Daikhin E, Yudkoff M, McMahon SB, Thompson CB. Myc regulates a transcriptional program that stimulates mitochondrial glutaminolysis and leads to glutamine addiction. Proc Natl Acad Sci U S A. 2008; 105:18782-18787. [PubMed: 19033189]

Wise DR, Ward PS, Shay JE, Cross JR, Gruber JJ, Sachdeva UM, Platt JM, DeMatteo RG, Simon MC, Thompson CB. Hypoxia promotes isocitrate dehydrogenase-dependent carboxylation of alphaketoglutarate to citrate to support cell growth and viability. Proc Natl Acad Sci U S A. 2011; 108:19611-19616. [PubMed: 22106302]

Wroblewska B, Santi MR, Neale JH. N-acetylaspartylglutamate activates cyclic AMP-coupled metabotropic glutamate receptors in cerebellar astrocytes. Glia. 1998; 24:172-179. [PubMed: 9728763]

Wronski M, Arbit E. Surgical treatment of brain metastases from melanoma: a retrospective study of 91 patients. Journal of neurosurgery. 2000; 93:9-18. [PubMed: 10883899]

Yip D, Le MN, Chan JL, Lee JH, Mehnert JA, Yudd A, Kempf J, Shih WJ, Chen S, Goydos JS. A phase 0 trial of riluzole in patients with resectable stage III and IV melanoma. Clin Cancer Res. 2009; 15:3896-3902. [PubMed: 19458050]

Yoo BC, Jeon E, Hong SH, Shin YK, Chang HJ, Park JG. Metabotropic glutamate receptor 4-mediated 5-Fluorouracil resistance in a human colon cancer cell line. Clin Cancer Res. 2004; 10:41764184. [PubMed: 15217955]

Yu LJ, Wall BA, Chen S. The current management of brain metastasis in melanoma: a focus on riluzole. Expert Rev Neurother. 2015; 15:779-792. [PubMed: 26092602]

Zamboni N. 13C metabolic flux analysis in complex systems. Curr Opin Biotechnol. 2011; 22:103108. [PubMed: 20833526]

Zhang C, Yuan XR, Li HY, Zhao ZJ, Liao YW, Wang XY, Su J, Sang SS, Liu Q. Anti-cancer effect of metabotropic glutamate receptor 1 inhibition in human glioma U87 cells: involvement of $\mathrm{PI} 3 \mathrm{~K} / \mathrm{Akt} / \mathrm{mTOR}$ pathway. Cellular physiology and biochemistry : international journal of experimental cellular physiology, biochemistry, and pharmacology. 2015; 35:419-432.

Zhao H, Desai V, Wang J, Epstein DM, Miglarese M, Buck E. Epithelial-mesenchymal transition predicts sensitivity to the dual IGF-1R/IR inhibitor OSI-906 in hepatocellular carcinoma cell lines. Molecular cancer therapeutics. 2012; 11:503-513. [PubMed: 22161861]

Zhu H, Reuhl K, Zhang X, Botha R, Ryan K, Wei J, Chen S. Development of heritable melanoma in transgenic mice. J Invest Dermatol. 1998; 110:247-252. [PubMed: 9506443] 


\section{Highlights}

- $\quad$ Tumor cells consume excessive glutamine for energy and macromolecule synthesis

- mGluRs play a role in progression and maintenance of brain and nonneuronal tumors

- $\quad$ Riluzole, a glutamate release inhibitor, can be a radiosensitizer in some cancers

- mGluR1 participates in crosstalk with the PI3K/AKT/mTOR and the IGF-1R pathways

- $\quad$ Functional mGluR1 may enhance angiogenesis in melanoma and breast cancer 


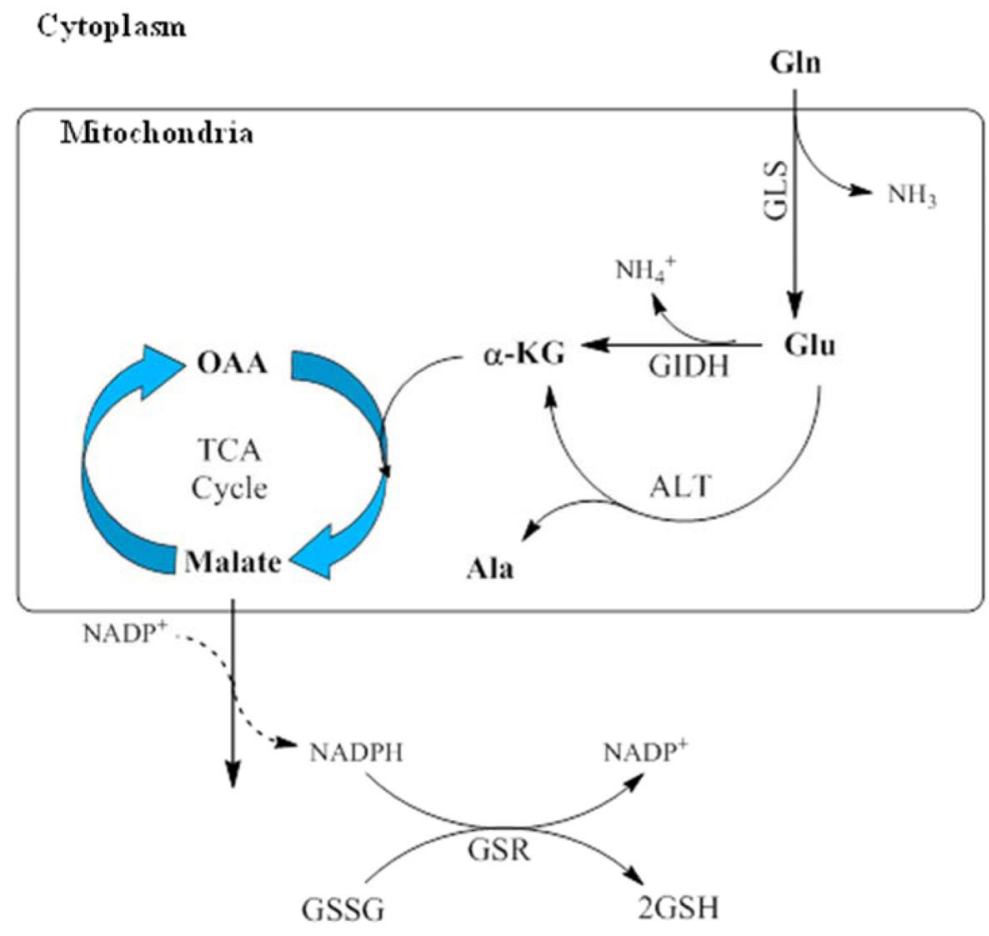

Figure 1. Glutamate metabolism in the mitochondria

Glutamine (Gln) is converted to glutamate (Glu) by the enzyme glutaminase (GLS) releasing both Glu and ammonia into the cytosolic compartment of the inner mitochondrial

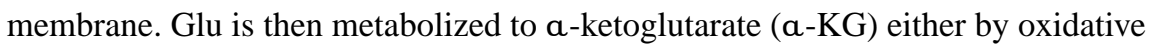
deamination by glutamate dehydrogenase (GIDH) or alanine transaminase (ALT). $a-K G$ is metabolized in the tricarboxylic acid (TCA) cycle to oxaloacetate through the production of malate. Malate oxidation to pyruvate in the cytosol generates NADPH which is used to maintain glutathione in its reduced state. 


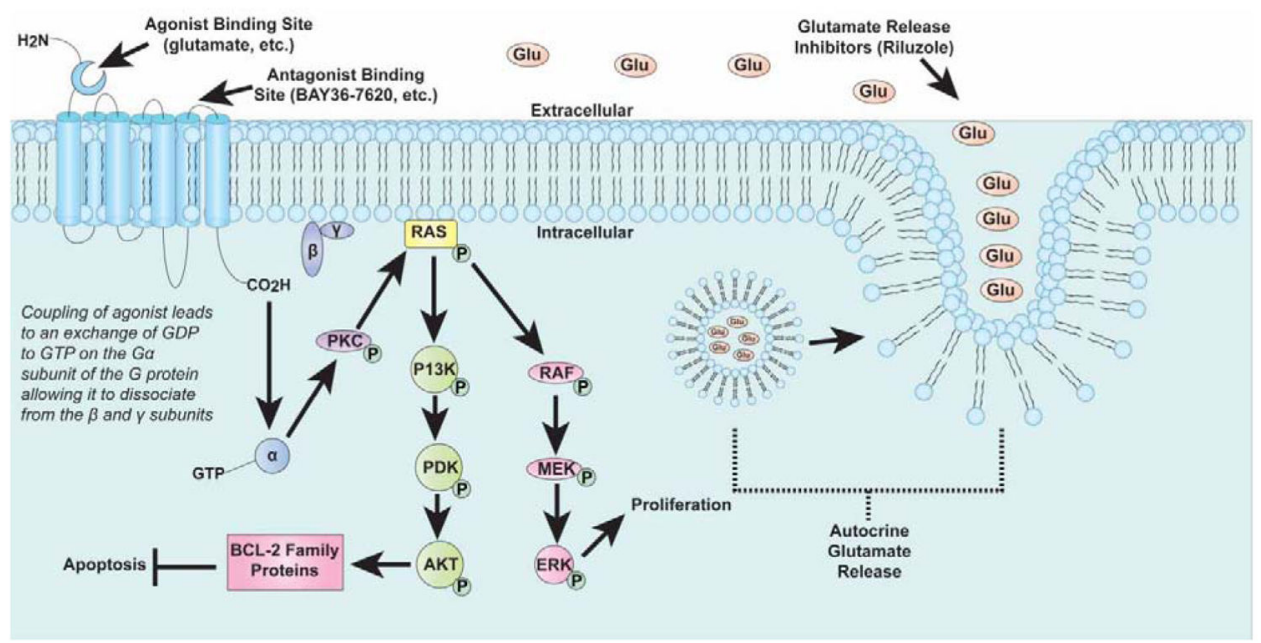

Figure 2.

Overall working hypothesis of the mechanisms involved in melanoma development through GRM1 activation. 


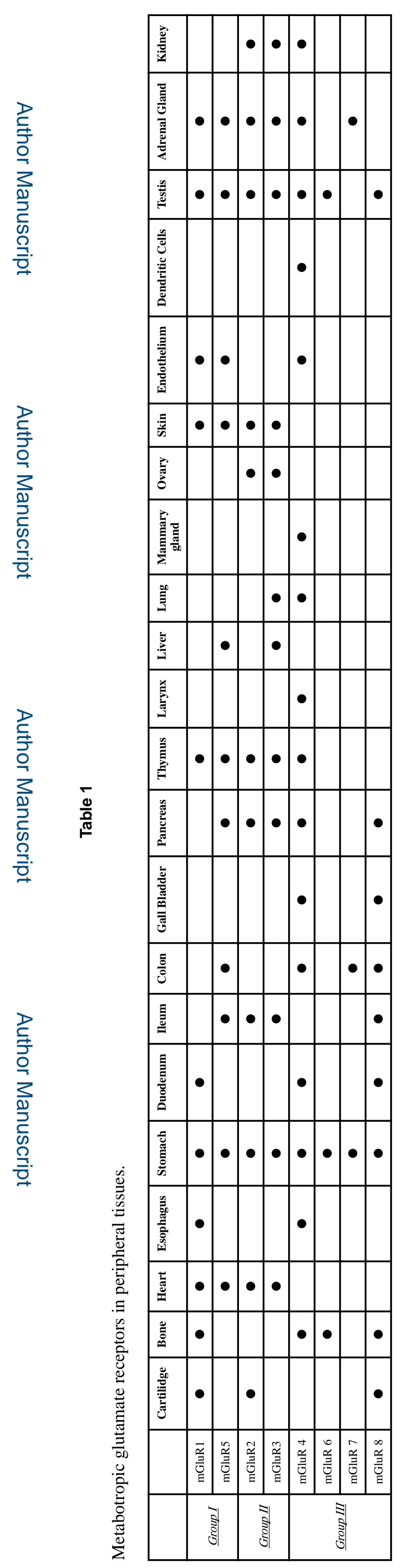

Neuropharmacology. Author manuscript; available in PMC 2018 March 15. 


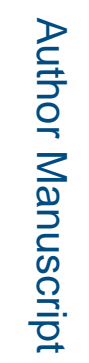

要

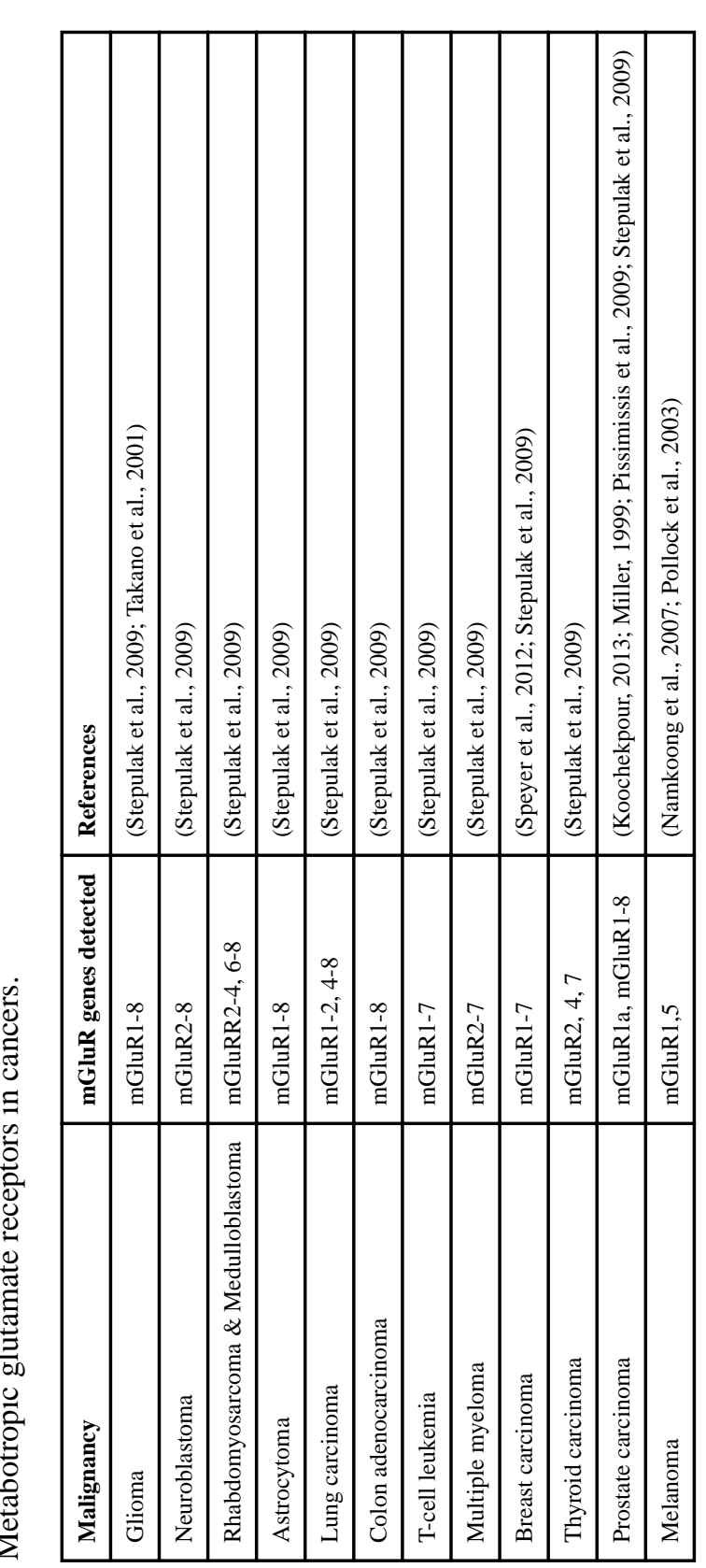

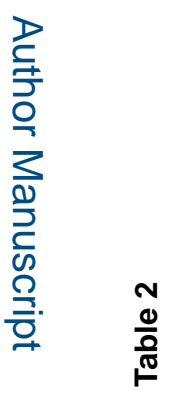

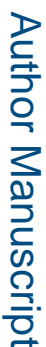

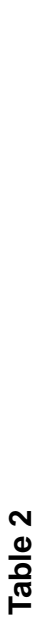

ᄅ

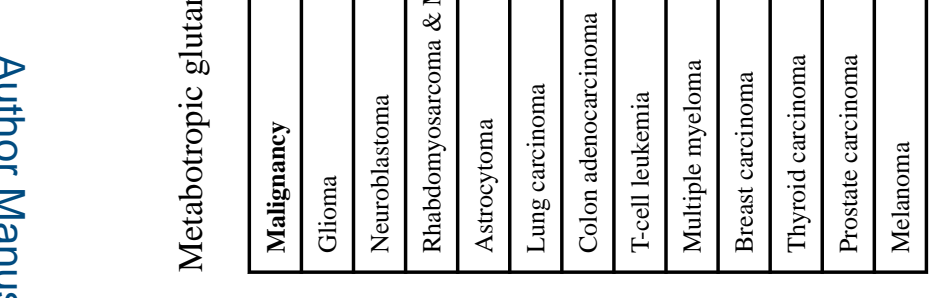

Neuropharmacology. Author manuscript; available in PMC 2018 March 15. 